Vol. 2 No. 1 Bulan Juni Tahun 2021

Halaman: 62 - 74

\title{
LAYANAN PEMBIAYAAN BERBASIS TEKNOLOGI INFORMASI BERDASARKAN PRINSIP SYARIAH: TINJAUAN FATWA DSN NOMOR 117/DSN-MUI/II/2018
}

\author{
DOI : https://doi.org/10.47281/fas.v2i1.49
}

\author{
Suyuti Dahlan Rifa'i', Hijriatu Sakinah' \\ Fakultas Syariah dan Hukum, Universitas Islam Negeri Sunan Kalijaga Yogyakarta ${ }^{1}$ \\ Fakultas Syariah dan Hukum, Universitas Islam Negeri Sunan Kalijaga Yogyakarta ${ }^{2}$ \\ Email: suyutirifai99@gmail.com ${ }^{1}$ \\ Email: hijriatusakinah99@gmail.com²
}

\begin{abstract}
The development of information technology not only covers social, political and cultural but also affects the economy. One that is being widely discussed is Fintech. This article aims to analyze fintech on PT. iGrow Resources Indonesia towards fatwa DSN number 117 / DSN-MUI / II / 2018 about information technology-based financing services based on sharia principles. This research is a library research using a descriptive analysis approach. PT. iGrow is not directly participate in the lending and borrowing process but provides a digital technology-based platform to facilitate the lending-borrowing process. The development of technology and information, especially Peer to Peer $(P 2 P)$ Lending, has made innovation in fintech-based financial services more practical and modern. The concept of adapting to technological developments combined with the financial sector by iGrow which was development step that is very aware of the needs of fintech for the business world. Regarding the extent to which the Islamic principles applied in PT. iGrow, can be seen in the discussion of the agreement. It is concluded that the standard contract is not in accordance with sharia principles based on the DSN fatwa number 117 / DSN-MUI / II / 2018 concerning information technology-based financing services based on sharia principles.
\end{abstract}

Keywords: Contract, Fintech, iGrow, Sharia,

\begin{abstract}
Abstrak
Perkembangan teknologi informasi tidak hanya mencakup kehidupan sosial, politik, dan budaya tetapi juga berpengaruh terhadap perekonomian. Salah satu yang sedang ramai diperbincangkan adalah Fintech. Artikel ini bertujuan untuk menganalisa fintech di PT. iGrow Resources Indonesia berdasarkan fatwa DSN nomor 117/DSN-MUI/II/2018 tentang layanan pembiyaan berbasis teknologi informasi berdasarkan prinsip syariah. Penelitian ini merupakan penelitian kepustakaan (library research) dengan menggunakan pendekatan deskriptif analisis. PT. iGrow tidak turun langsung dalam proses pinjam meminjam tetapi menyediakan platform berbasis teknologi digital dalam memfasilitasi proses pinjam-meminjam. Perkembangan teknologi dan informasi khususnya Peer to Peer (P2P) Lending telah menciptakan inovasi layanan keuangan berbasis fintech menjadi semakin praktis dan modern. Konsep adaptasi perkembangan teknologi yang dipadukan dengan bidang financial oleh iGrow merupakan langkah pengembangan bisnis yang sangat menyadari kebutuhan fintech bagi dunia bisnis. Terkait sejauh mana prinsip syariah yang diterapkan dalam PT. iGrow, dapat dilihat pada pembahasan akad dalam kontrak. Disimpulkan bahwa kontrak baku belum sesuai dengan prinsip syariah berdasarkan fatwa DSN nomor 117/DSN-MUI/II/2018 tentang layanan pembiyaan berbasis teknologi informasi berdasarkan prinsip syariah.
\end{abstract}

Kata Kunci: Fintech, iGrow, Kontrak, Syariah 


\section{Fastabiq: Jurnal Studi Islam \\ ISSN 2723-0228}

Vol. 2 No. 1 Bulan Juni Tahun 2021

\section{PENDAHULUAN}

Artikel ini berfokus pada implementasi fatwa dsn nomor 117/dsn-mui/i/2018 tentang layanan pembiyaan berbasis teknologi informasi berdasarkan prinsip syariah terhadap PT. igrow resources indonesia. Alasan arrtikel ini dikaji karena kasus sebuah perusahaan rintisan berbasis teknologi digital yang kini ramai disebut sebagai startup digital adalah terkait dengan begitu fenomenalnya distruptive innovation (distruption) yang dibawa oleh iklim startup di tanah air ${ }^{1}$ Dari berbagai startup yang ada igrow merupakan salah satu paltfrom yang menyuguhkan inovasi terbaru dibidang pertanian ditanah air yang terdaftar di OJK dan sesuai prinsip syariah.

Hukum syariah dalam berekonomi tidak hadir sebatas untuk pelaku usaha yang mendeklarasikan diri dengan label syariah. Namun, hadir untuk semua pelaku bisnis yang beragama Islam dan yang terikat didalam kontrak sebagai panduan dalam menjalankan bisnis. Friederich Karl Von Savigny menyatakan bahwa "hukum itu tidak dibuat, melainkan tumbuh dan berkembang, bersama dengan masyarakat". ${ }^{2}$ Dalam Islam dikenal suatu kaidah "tanahin nus\}u>s wa'adamu tanahi> al-waqo>'i" dalil-dalil nash telah berhenti, akan tetapi kasus-kasus baru tidak berhenti. Oleh sebab itu ijtihad ada, termasuk lahirlah fatwa-fatwa. ${ }^{3}$

Perkembangan teknologi informasi tidak hanya mencakup kehidupan sosial, politik, dan budaya tetapi juga berpengaruh terhadap perekonomian. Salah satu yang sedang ramai diperbincangkan adalah Fintech Syariah. Fintech merupakan singkatan dari Financing and Technology. Fintech didefinisikan sebagai inovasi teknologi dalam layanan keuangan yang dapat menghasilkan model-model bisnis, aplikasi, proses atau produk-produk dengan efek material yang terkait dengan penyediaan layanan keuangan.

Fintech ini dilaksanakan dengan berlandaskan hukum yang tertuang dalam Fatwa DSN-MUI No.117/DSN-MUI/II/2018 tentang Layanan Pembiayaan Berbasis Teknologi Informasi Berdasarkan Prinsip Syariah. Di dalam fatwa diantaranya: factoring, purchases order, online seller, payment gateway, pembiayaan pegawai, dan pembiayaan berbasis komunitas. Akad yang ada dalam fatwa tersebut adalah akad wakalah bil ujrah, musyarakah, qardh, jual beli, wakalah, ijarah dan mudharabah. Kemudahan yang fintech berikan berjalan beriringan dengan rentannya risiko yang akan didapatkan oleh konsumen. Berbagai perusahaan menawarkan produk investasinya dengan berbagai macam strategi pemasaran, tanpa terkecuali PT iGrow Resources Indonesia yang bergerak khusus di fintech bidang pertanian. PT iGrow Resources menyelenggartakan aktifitas pinjam meminjam berbasis teknologi digital melalui aplikasi "iGrow: Pembiayaan Pertanian Aman dan Menguntungkan" menggunakan prinsip bagi hasil. ${ }^{4}$

PT iGrow Resources Indonesia adalah sebuah perusahaan investasi di Indonesia dalam bidang pertanian yang fokus untuk membantu petani lokal, mengoptimalkan lahan, dan menjembatani investor penanaman dengan petani untuk menghasilkan produk pertanian organik berkualitas. ${ }^{5}$ PT iGrow telah terdaftar di Otoritas Jasa Keuangan dengan Nomor S4438/NB.111/2017 pada tanggal 18 September 2017. Platform investasi ini adalah fintech jenis peer 


\section{Fastabiq: Jurnal Studi Islam \\ ISSN 2723-0228}

Vol. 2 No. 1 Bulan Juni Tahun 2021

to peer lending. Layanan pinjam meminjam uang yang terjadi antara investor atau sponsor, dan petani. Produk investasi ini sebagaimana yang dikemukakan oleh OJK sangat menarik, karena akan menghasilkan return bagi hasil bagi pelaku usaha. ${ }^{6}$

\section{METODE PENELITIAN}

Penelitian ini merupakan penelitian kepustakaan (library research). Data-data yang digunakan dalam penelitian ini adalah data sekunder berupa Fatwa DSN-MUI No.117/DSNMUI/II/2018 tentang Layanan Pembiayaan Berbasis Teknologi Informasi Berdasarkan Prinsip Syariah, serta sumber lainnya berupa buku, jurnal, dan sumber-sumber lain yang relevan dengan penelitian ini. Data-data yang ada tersebut dianalisis menggunakan teknik deskriptif analisis.

\section{HASIL DAN PEMBAHASAN}

\section{Financial Technology (Fintech) atau Teknologi Finansial}

Definisi Fintech seperti yang dijabarkan oleh National Digital Research Centre (NDRC) adalah istilah yang digunakan untuk menyebut suatu inovasi dibidang jasa financial financial yang mengacu pada inovasi financial dengan sentuhan teknologi modern. ${ }^{7}$ Fintech merupakan salah satu bentuk penerapan teknologi informasi dibidang keuangan dengan muncul berbagai model keuangan baru dimulai pertama kali pada tahun 2004 oleh Zopa, yaitu institusi keuangan yang berada di Inggris yang menjalankan jasa peminjaman uang. ${ }^{8}$

Konsep Finance Technology merupakan bentuk adaptasi dari perkembangan teknologi yang dipadukan dengan bidang keuangan. Awal mula teknologi ini dimulai dengan istilah start up. Start up masih merupakan konsep tentang model bisnis yang masih dalam rangka uji coba, sedangkan finance technology merupakan hasil jadinya. ${ }^{9}$ Dengan adanya perkembangan ini maka diharapkan bisa memfasilitasi proses transaksi keuangan yang lebih praktis dibandingkan dengan transaksi keuangan yang tradisional. Diharapkan dengan adanya fintech dapat diciptakan proses transaksi keuangan yang lebih praktis dan lebih modern. Layanan yang dilakukan meliputi payment channel system, digital banking, online digital insurance, Peer to Peer $(P 2 P)$ Lending serta layanan crowd funding. ${ }^{10}$

Menurut Peraturan Bank Indonesia No. 19/12/PBI/2017 menjelaskan bahwa Teknologi Finansial adalah penggunaan teknologi dalam sistem keuangan yang menghasilkan produk, layanan, teknologi, dan atau model bisnis baru serta dapat berdampak pada stabilitas moneter, stabilitas sistem keuangan, dan atau profesionali, efisiensi, kelancaran, keamanan, dan keandalan sistem pembayaran. ${ }^{11}$ Secara spesifik fintech didefinisikan sebagai aplikasi teknologi digital untuk masalah-masalah intermediasi keuangan.

Lebih luas lagi fintech didefinisikan sebagai sebuah industri yang terdiri dari perusahaanperusahaan yang menggunakan teknologi agar sistem keuangan serta penyampaian layanan keuangan lebih efisien. Dari beberapa pengertian di atas dapat disimpulkan bahwa fintech adalah

ANALISA FINTECH TERHADAP PT. IGROW RESOURCES INDONESIA DITINJAU BERDASARKAN FATWA DSN

NOMOR 117/DSN-MUI/II/2018 TENTANG LAYANAN PEMBIYAAN BERBASIS TEKNOLOGI INFORMASI BERDASARKAN PRINSIP SYARIAH

Suyuti Dahlan Rifa'i, Hijriatu Sakinah 


\section{Fastabiq: Jurnal Studi Islam \\ ISSN 2723-0228}

Vol. 2 No. 1 Bulan Juni Tahun 2021

penggunaan teknologi informasi dalam sistem keuangan untuk meningkatkan efektivitas dan efisiensi kegiatan layanan keuangan untuk memecahkan masalahmasalah intermediasi keuangan. ${ }^{12}$

\section{Klasifikasi Fintech}

Ada beberapa kategori layanan fintech yang ada di Indonesia, dalam perkembangannya ada beberapa macam jenis fintech, antara lain yaitu:

a. Deposits, lending, capital raising, layanan pada kategori ini di antaranya adalah crowdfunding dan peer to peer lending.

b. Investment dan risk management layanan pada kategori ini adalah robo advice, e-trading, dan insurance.

c. Payments, clearing dan settlement beberapa layanan pada kategori ini adalah mobile payment (misalnya $\mathrm{p} 2 \mathrm{p}$ transfer, apple/samsung pay), web based payment (invoice payment paypal), serta termasuk yang menggunakan digital currency. ${ }^{13}$

\section{Peer to Peer Lending (P2PL)}

Peer to peer lending (P2PL) atau biasa disebut person-to-person lending adalah salah satu crowdfunding berupa praktik pemberian pinjaman dimana si peminjam dan pemberi pinjaman (investor) dipertemukan melalui platform yang disediakan oleh perusahaan P2PL. P2PL inilah yang akan menjadi fokus dari kajian artikel ini berupa platform yang bergerak dibidang pertanian yaitu PT. iGrow resources Indonesia. Platform investasi ini adalah fintech jenis peer to peer lending. Layanan pinjam meminjam uang yang terjadi antara investor atau sponsor, dan petani. Produk investasi ini sebagaimana yang dikemukakan oleh OJK sangat menarik, karena akan menghasilkan return bagi hasil bagi investor.

Pada dasarnya, sistem Peer to Peer Lending ini sangat mirip dengan konsep marketplace untuk kegiatan pinjam-meminjam uang secara online yang menyediakan wadah sebagai tempat pertemuan antara pembeli dengan penjual. Dalam hal Peer to Peer Lending ini,sistem yang ada akan mempertemukan pihak Peminjam dengan pihak yang memberikan pinjaman. Sebagai alternatf dari pinjaman melalui lembaga resmi sepert bank, koperasi, jasa kredit, pemerintah dan sebagainya yang prosesnya jauh lebih kompleks, masyarakat bisa mengajukan pinjaman kepada masyarakat melalui sistem Peer to Peer Lending.

$\mathrm{Hal}$ ini tentu berbeda dengan sifat pinjaman dari bank yang menerapkan prinsip $5 \mathrm{C}$, yakni Character, Capacity, Capital, Collateral, Conditon sebagai acuan kelayakan. Kredit secara umum merupakan pinjaman dalam bentuk uang dan/ atau bentuk lainnya yang diberikan melalui persetujuan, dengan jangka waktu dan bunga. ${ }^{14}$ Setap perjanjian, khususnya perjanjian kredit antara bank dengan nasabah wajib menerapkan asas-asas dalam perjanjian. Walaupun tidak menganut prinsip 5C selayaknya bank namun Peer to Peer Lending tetap harus memperhatkan kinerja dari Non-Performing Loan (NPL) perusahaannya.

ANALISA FINTECH TERHADAP PT. IGROW RESOURCES INDONESIA DITINJAU BERDASARKAN FATWA DSN NOMOR 117/DSN-MUI/II/2018 TENTANG LAYANAN PEMBIYAAN BERBASIS TEKNOLOGI INFORMASI 


\section{Fastabiq: Jurnal Studi Islam \\ ISSN 2723-0228}

Vol. 2 No. 1 Bulan Juni Tahun 2021

Sebagai penghubung antara Pemberi Pinjaman dengan Peminjam, Perusahaan penyedia layanan Peer to Peer Lending menggunakan data pribadi sebagai proses untuk mengenali nasabah atau yang kita kenal sebagai KYC (Know Your Customer), menilai kelayakan Peminjam, serta menyediakan layanan kepada para pengguna. Perusahaan penyedia layanan Peer to Peer Lending akan melakukan verifkasi data Pemberi Pinjaman, menyeleksi pinjaman dengan credit scoring, mengatur lalu lintas dana antara Peminjam dan Pemberi Pinjaman, serta melakukan monitoring selama periode pinjaman.

\section{Ketentuan Fatwa DSN-MUI NO. 117/DSN-MUI/II/20118 tentang Layanan Pembiayaan Berbasis Teknologi Informasi Berdasarkan Prinsip Syariah}

Dewan Syariah Nasional Majelis Ulama Indonesia mengeluarkan fatwa mengenai layanan pembiayaan berbasis teknologi informasi sesuai dengan prinsip syariah. Telah disebutkan dalam Fatwa DSN MUI Nomor 117/DSNMUI/II/2018 bahwa layanan pembiayaan berbasis teknologi informasi berdasarkan prinsip syariah merupakan penyelenggaraan layanan jasa keuangan yang didasarkan atas prinsip syariah yang menghubungkan antara pemberi pembiayaan dengan penerima pembiayaan untuk melakukan akad pembiayaan melalui sistem elektronik dengan bantuan jaringan internet. ${ }^{15}$

Pengertian layanan pembiayaan berbasis teknologi informasi dengan prinsip syariah artinya bahwa dalam melakukan pembiayaan harus disesuaikan dengan prinsip syariah sehingga terhindar dari adanya riba ataupun penanggungan kerugian yang tidak sesuai dengan syariah. Subjek hukum yang melakukan kegiatan layanan pembiayaan berbasis teknologi informasi antara lain penyelenggara, penerima pembiayaan dan pemberi pembiayaan. Akad yang digunakan dalam transaksi layanan pembiayaan berbasis teknologi informasi dengan prinsip syariah antara lain ijarah, bai', musyarakah, mudharabah, qardh dan wakalah bil ujrah.

Karena semua menggunakan sistem elektronik maka dibutuhkan adanya tandatangan elektronik dan sertifikat elektronik yang terjamin baik autentikasinya ataupun validitasnya. Pengenaan biaya menggunakan sistem ujrah dibolehkan asal disesuaikan dengan prinsip ijarah. Biaya operasional teknologi finansial didapatkan dari ujrah yang dibebankan kepada konsumen karena telah menggunakan jasa dari penyelenggara layanan pembiayaan berbasis teknologi informasi berdasarkan prinsip syariah. ${ }^{16}$

Macam-macam model layanan pembiayaan berbasis teknologi informasi meliputi pembiayaan anjak piutang, pembiayaan pengadaan barang untuk online reseller, pembiayaan pengadaan barang pesanan untuk pihak ketiga (purchase order), pembiayaan berbasis komunitas, pembiayaan pengadaan barang untuk e-commerce yang melakukan pembayaran dengan sistem payment gateway dan pembiayaan untuk pegawai. ${ }^{17}$ Menurut Fatwa DSN MUI Nomor 117/DSNMUI/II/2018 tentang Layanan Pembiayaan Berbasis Teknologi Informasi Berdasarkan Prinsip Syariah disebutkan bahwa pembiayaan-pembiayaan di atas merupakan jenis-jenis 


\section{Fastabiq: Jurnal Studi Islam \\ ISSN 2723-0228}

Vol. 2 No. 1 Bulan Juni Tahun 2021

pembiayaan yang diakui sebagai pembiayaan yang dibolehkan menurut prinsip syariah. Masingmasing pembiayaan memiliki akad yang berbeda satu sama lain.

Pembiayaan anjak piutang (factoring) menggunakan akad wakalah bil ujrah serta qardh. Akad tersebut terjadi antara pemberi pembiayaan dengan penyelenggara. Pemberi pembiayaan sebagai muwakki>l sedangkan penyelenggara sebagai wakil. Penyelenggara yang berkedudukan sebagai wakil dan pemberi pembiayaan selaku muwakkil bisa memberikan talangan dana menggunakan akad qardh kepada penerima pembiayaan. ${ }^{18}$ Penyelenggara yang berkedudukan sebagai wakil dari pemberi pembiayaan berhak menerima ujrah dan qardh dari penerima pembiayaan yang selanjutnya harus diserahkan pada pemberi pembiayaan.

Sama halnya dengan anjak piutang, pembiayaan pengadaan barang untuk online reseller juga menggunakan akad wakalah bil ujrah. Penyelenggara sebagai wakil dari pemberi pembiayaan dan pemberi pembiayaan merupakan muwakkil. Namun perbedaannya terletak pada akad yang terjadi antara penyelenggara dengan penerima pembiayaan. Akadnya bisa musyarakah, mudarabah ataupun melalui jual beli. Karena akadnya berbeda maka timbal balik yang diberikan kepada penyelenggara juga berbeda. Penerima pembiayaan memberikan margin ataupun bagi hasil kepada penyelenggara selaku wakil dari pemberi pembiayaan. Selain margin ataupun bagi hasil maka pokok pembiayaan juga wajib dikembalikan kepada pemberi pembiayaan melalui penyelenggara. ${ }^{19}$ Pengadaan barang pesanan (purchase order) pada pihak ketiga dan pembiayaan pengadaan barang pelaku e-commerce melalui penyelenggara payment gateway juga menggunakan akad yang sama dengan pembiayaan untuk online reseller.

Pembiayaan berbasis komunitas cakupan akadnya lebih luas lagi dibandingkan dengan akad-akad lainnya. Sekalipun sama-sama mengguanakan akad wakalah bil ujrah antara penyelenggara dan pemberi pembiayaan maka untuk akad antara penyelenggara dan penerima pembiayaan berbeda. Penerima pembiayaan dengan penyelenggara bisa berdasarkan akad yang bermacam-macam, bisa akad jual beli, mudharabah dan musyarakah serta akad-akad lainnya yang sesuai dengan prinsip syariah. Penerima pembiayaan membayar pokok serta imbalan yang bisa berupa margin, bagi hasil ataupun ujrah.

Pembiayaan terakhir yang dibiayai berdasarkan Fatwa DSN MUI Nomor 117/DSNMUI/II/2018 adalah pembiayaan untuk pegawai. Pembiayaan pegawai merupakan pembiayaan yang sifatnya konsumtif sehingga akad yang dilakukan juga berbeda. Akad yang dilakukan antara penyelenggara dengan pemberi pembiayaan sama yakni wakalah bil ujrah dengan penyelenggara sebagai wakil sedangkan pemberi pembiayaan sebagai muwakkil. Akad yang terjadi antara penyelenggara dengan pemberi pembiayaan yakni akad jual beli atau ijarah. Penerima pembiayaan mengembalikan pokok pembiayaan disertai dengan imbal hasil berupa margin atau ujrah dengan pemotonga gaji (auto debet). ${ }^{20}$

Peer to peer lending yang dilakukan oleh teknologi finansial yang didasarkan atas prinsip syariah juga menggunakan akad wakalah bil ujrah. Jika terjadi akad tambahan berupa investasi 


\section{Fastabiq: Jurnal Studi Islam \\ ISSN 2723-0228}

Vol. 2 No. 1 Bulan Juni Tahun 2021

maka akad yang dilakukan bisa dengan musyarakah atau mudharabah tergantung kesepakatan dari masing-masing pihak. Pembagian profit and loss sharing yang dilakukan para pihak juga didasarkan atas kesepakatan tanpa memberatkan masing-masing pihak. Prinsip syariah merupakan prinsip yang sesuai dengan syariat Islam dengan niatnya merupakan pemberian pertolongan dengan mendapatkan profit and loss sharing yang tidak memberatkan. ${ }^{21}$

\section{iGrow Resources Indonesia}

iGrow adalah sebuah platform digital yang jenis fintech P2PL yang fokus untuk membantu petani lokal, lahan yang belum optimal diberdayakan, dan para investor penanaman untuk menghasilkan produk pertanian oraganik. iGrow bertindak sebagai jembatan penghubung antara petani, pemilik tanah, dan investor ${ }^{22}$. Ketiganya dipertemukan untuk menghasilkan suatu produk pertanian yang cocok dengan keadaan tanah dan cuaca yang sudah diteliti oleh tim iGrow untuk meminimalkan risiko. Investasi ini menjadi lahan penghasilan untuk petani, pemilik lahan dan investor. iGrow menciptakan model pertanian baru yang scalable dan efisien. Selain menghubungkan ketiga unsur yang disebutkan sebelumnya, iGrow juga menghubungkan produk kepada pembeli. Sehingga saat produk panen sudah ada pasar yang akan membeli.

iGrow merupakan perusahaan agrobisnis yang berawal dari sebuah kebun di Jonggol Farm milik Muhaimin lqbal. la disebut sebagai spiritualitas agro. iGrow pun lahir dari semangat spiritual. Karena Muhaimin lqbal selaku founder tumbuh besar dengan ajaran Islam yang kuat. la terinspirasi dari surat Hud ayat 61 yang konklusinya bahwa manusia diciptakan dari tanah, dan manusia harus mengolah tanah untuk memakmurkan dunia. Cara bertani iGrow ia ambil dari menkaji al-Quran terkait pertanian. $^{23}$

Setiap perusahaan tentu memiliki tujuan masing-masing. iGrow yang bergerak di sektor pangan memiliki tujuan sendiri, yang berbeda dengan perusahaan profit pada umumnya. Founder iGrow melihat banyak lahan yang tidak optimal digunakan terutama di Indonesia, dan terdapat pula jutaan orang yang hidup digaris kemiskinan karena hasil pekerjaan yang tidak mencukupi. Sementara kebutuhan dan permintaan masyarakat atas makanan dari produk pertanian semakin tinggi, selaras semakin bertambahnya angka kelahiran penduduk.

\section{Jenis Produk}

iGrow dalam produk investasinya menyediakan produk dari jenis investasi bidang pertanian, pakan ternak dan peternakan. Dengan jangka waktu kontrak yang berbeda-beda. Adapun jenis produknya yaitu:

a. Produk investasi jangka pendek 


\section{Fastabiq: Jurnal Studi Islam \\ ISSN 2723-0228}

Vol. 2 No. 1 Bulan Juni Tahun 2021

Jangka waktu paling pendek dari produk investasi iGrow adalah selama enam bulan. Ratarata panen adalah setelah satu tahun. Dengan kisaran prosentase bagi hasil bersih untuk investor adalah sebesar 9-20 persen.

b. Produk investasi jangka panjang

Sedangkan untuk jangka panjang hingga saat ini paling lama kontrak sampai depan belas tahun. Baik produk investasi jangka panjang maupun jangka pendek keduanya masih didominasi jenis produk investasi pertanian. ${ }^{24}$

\section{Sistem Kerja dalam iGrow}

Ada beberapa langkah yang harus dilalui investor iGrow sehingga sampai pada tahap bagi hasil, diantaranya: ${ }^{25}$

a. Beli bibit

Investor menelusuri bibit-bibit yang tersedia. Kemudian memilih benih yang tepat sesuai dengan budget dan kemungkinan bagi hasil yang paling menarik.

b. Pantau Perkembangan

Investor dapat memantau perkembangan bibit yang diinvetasikan dengan update foto, tinggi dan komentar terbaru dari para surveyor iGrow di lapangan secara real time melalui fitur monitoring yan tersedia di aplikasi. Jual Hasil Panen Semua hasil panen akan dijual ke partner yang telah bekerjasama dengan iGrow.

c. Bagi Hasil

Semua bagi hasil akan dirangkum oleh iGrow dalam bentuk laporan keuangan yang lengkap. Bagi hasil dikirim pihak iGrow ke akun bank yang didaftarkan di akun iGrow investor.

\section{Analisa Fintech Terhadap PT. iGrow Resources Indonesia Ditinjau Berdasarkan Fatwa DSN Nomor 117/DSN-MUI/II/2018 Tentang Layanan Pembiyaan Berbasis Teknologi Informasi Berdasarkan Prinsip Syariah}

Fintech merupakan singkatan dari Financial Technology, fintech didefiniskan sebagai penggunaan terknologi dalam sisten keuangan yang menghasilkan produk layanan, teknologi, dan/atau model bisnis baru serta dapat berdampak pada stabilitas moneter, stabilitas sistem keuangan, dan/atau efisiensi, kelancaran, keamanan dan Kendala sistem pembayaran. ${ }^{26}$

Fintech memiliki peran penting dalam inovasi layanan keuangan yaitu dapat mengakses data dan informasi kapan dan dimana saja untuk kegiatan bisnis, peran teknologi informasi pada aktifitas bisnis adalah menggantikan atau memperkuat peran manusia terhadap suatu tugas dan proses. Fintech ini dilaksanakan dengan berlandaskan hukum yang tertuang dalam Fatwa DSN-MUI No.117/DSN-MUI/II/2018 tentang Layanan Pembiayaan Berbasis Teknologi Informasi Berdasarkan Prinsip Syariah. Di dalam fatwa diantaranya: factoring, purchases order, online seller, payment gateway, pembiayaan pegawai, dan pembiayaan berbasis komunitas. Akad yang ada dalam fatwa ANALISA FINTECH TERHADAP PT. IGROW RESOURCES INDONESIA DITINJAU BERDASARKAN FATWA DSN NOMOR 117/DSN-MUI/II/2018 TENTANG LAYANAN PEMBIYAAN BERBASIS TEKNOLOGI INFORMASI 


\section{Fastabiq: Jurnal Studi Islam \\ ISSN 2723-0228}

Vol. 2 No. 1 Bulan Juni Tahun 2021

tersebut adalah akad wakalah bil ujrah, musyarakah, qardh, jual beli, wakalah, ijarah dan mudharabah. Berbagai perusahaan menawarkan produk investasinya dengan berbagai macam strategi pemasaran, tanpa terkecuali PT iGrow Resources Indonesia yang bergerak khusus di fintech bidang pertanian.

PT iGrow Resources Indonesia adalah sebuah perusahaan investasi di Indonesia dalam bidang pertanian yang fokus untuk membantu petani lokal, mengoptimalkan lahan, dan menjembatani investor penanaman dengan petani untuk menghasilkan produk pertanian organik berkualitas. $^{27}$

Jenis fintech yang digunakan iGrow bila dilihat dari karakteristiknya masuk ke dalam jenis

fintech yang terakhir tercantum dalam Fatwa DSN Nomor 117/DSN-MUI/II/2018 Tentang Layanan Pembiayaan Berbasis Teknologi Informasi Berdasarkan Prinsip Syariah yaitu Pembiayaan Berbasis Komunitas. Setidaknya ada 7 ketentuan dalam penyelenggaraannya, antara lain: ${ }^{28}$

a. Adanya pelaku usaha/calon Penerima Pembiayaan yang tergabung dalam komunitas usaha tertentu yang bekerjasamadengan Penyelenggara; "Calon penerima pembiayaan atau mitra pelaku usaha iGrow adalah komunitas petani yang telah bekerjasama dengan iGrow."

b. Calon Penerima Pembiayaan, mengajukan pembiayaan kepada Penyelenggara iGrow;.

c. Atas dasar pengajuan sebagaimana huruf $b$, penyelenggara menawarkan kepada calon Pemberi Pembiayaan untuk membiayai kebutuhan modal calon Penerima Pembiayaan; "Dunia bisnis mengenal dua kemungkinan. Yaitu : Pelaku usaha mengajukan permohonano pembiayaan, atau pemilik modal mewarkan pembiayaan."

d. Dalam hal calon Pemberi Pembiayaan menyetujui penawaran sebagaimana huruf c, dilakukan akad wakalah bi al-ujrah antara Pemberi Pembiayaan dengan Penyelenggara untuk memberikan pembiayaan kepada Penerima Pembiayaan; Pemberi Pembiayaan sebagai muwakkil, dan Penyelenggara sebagai wakil. "iGrow sebagai pemberi dana (wakil invenstor) atau disebut sebagai Surveyor, memberi pendanaan modal kepada para petani yang prosesnya menggunakan aplikasi berbasis teknologi digital, dengan tujuan meningkatkan skala penanaman/budi daya sehingga dapat meningkatkan kesejahteraan para pelaku dunia pertanian, selanjutnya iGrow memantau penyelenggaraan dilapangan dan disampaikan kepada investor".

e. Penyelenggara sebagai wakil dari Pemberi Pembiayaan, melakukan akad dengan Penerima Pembiayaan baik akad jual beli, ijarah, musyarakah, mudharabah, atau akad-akad lain yang sesuai dengan prinsip syariah; "akad yang digunakan dalam investasi ini adalah wakalah bil ujrah dan mudharabah. Sebagaimana tercantum pada poin 4 syarat dan ketentuan dalam kontrak baku iGrow. ${ }^{29}$ 


\section{Fastabiq: Jurnal Studi Islam \\ ISSN 2723-0228}

Vol. 2 No. 1 Bulan Juni Tahun 2021

f. Penerima pembiayaan membayar pokok dan imbal hasil (margin, ujrah atau bagi hasil) kepada Penyelenggara melalui komunitas usaha tertentu yang bekerjasama dengan Penyelenggara; ${ }^{30}$

g. Penyelenggara wajib menyerahkan pokok dan imbal hasil (margin atau ujrah) kepada Pemberi Pembiayaan. ${ }^{31}$

Jika dilihat dari huruf e, maka dapat diketahui akad yang digunakan oleh PT. iGrow_adalah akad mudhorobah antara investor dan penerima pinjaman serta wakalah bil ujroh antara para pihak dan iGrow. PT. iGrow tidak turun langsung dalam proses pinjam meminjam tetapi menyediakan platform berbasis teknologi digital dalam memfasilitasi proses pinjam-meminjam. Platform tersebut dapat diunduh melalui media Playsore atau Appstore dengan nama aplikasi "iGrow : Pembiayaan Pertanian Aman dan Menguntungkan". iGrow sebagai perusahaan agrobisnis yang berawal dari sebuah kebun di Jonggol Farm milik Muhaimin Iqbal, lahir dari semangat spiritual terinspirasi dari surat Hud ayat 61 yang konklusinya bahwa manusia diciptakan dari tanah, dan manusia harus mengolah tanah untuk memakmurkan dunia. Cara bertani iGrow ia ambil dari menkaji al-Quran terkait pertanian. ${ }^{32}$

Terkait sejauh mana prinsip syariah yang diterapkan dalam PT. iGrow, dapat dilihat pada pembahasan akad dalam kontrak sebagai dasar penyelenggaraan suatu transaksi. Adapun akad yang dipakai iGrow adalah akad mudhorobah antara investor dan penerima pinjaman serta wakalah bil ujroh antara para pihak dan iGrow. Fatwa DSN MUI No 117 tentang Layanan Pembiayaan Berbasis Teknologi Informasi Berdasarkan Prinsip Syariah pada bagian pedoman umum poin kedua, berbunyi:"Akad Baku yang dibuat Penyelenggara wajib memenuhi prinsip keseimbangan, keadilan, dan kewajaran sesuai syariah dan peraturan perundang-undangan". ${ }^{33}$ Yang juga harus diperhatikan dengan cermat adalah, berdasarkan data yang dikutip dalam Farihah Mahmudah (2019). ${ }^{34}$ Bahwa terdapat inkonsisten kontrak baku iGrow yang secara tegas menggunakan istilah presentasi bagi hasil bukan bunga pinjaman bertentangan dengan Pasal 18 ayat 2, Undang-Undang Nomor 8 Tahun 1999 Tentang Perlindungan Konsumen. Sehingga disimpulkan, secara materiil dan formil kontrak baku belum sesuai dengan prinsip syariah berdasarkan fatwa DSN nomor 117/DSN-MUI/II/2018 tentang layanan pembiyaan berbasis teknologi informasi berdasarkan prinsip syariah.

Meski demikian kenyataan yang terjadi adalah perkembangan teknologi dan informasi khususnya Peer to Peer (P2P) Lending, telah menciptakan inovasi layanan keuangan berbasis fintech menjadi semakin praktis dan modern. Hal ini kiranya sesuai dengan definisi pembiayaan yang memanfaatkan sistem elektronik sebagaimana tertuang dalam fatwa DSN nomor 117/DSN$\mathrm{MUI} / \mathrm{Il} / 2018$ tentang layanan pembiyaan berbasis teknologi informasi berdasarkan prinsip syariah pada ketentuan umum angka 1, menyatakan 'Layanan Pembiayaan Berbasis Teknologi Informasi Berdasarkan Prinsip Syariah adalah penyelenggaraan layanan jasa keuangan berdasarkan prinsip syariah yang mempertemukan atau menghubungkan Pemberi Pembiayaan dengan Penerima 


\section{Fastabiq: Jurnal Studi Islam}

ISSN 2723-0228

Vol. 2 No. 1 Bulan Juni Tahun 2021

Pembiayaan dalam rangka melakukan akad pembiayaan melalui sistem elektronik dengan menggunakan jaringan internet". ${ }^{35}$

Kini hadir sebuah sistem pinjam meminjam yang diwadahi suatu platform untuk meningkatkan efektifitas dan efesiensi kegiatan layanan keuangan. Konsep adaptasi perkembangan teknologi yang dipadukan dengan bidang financial oleh iGrow merupakan langkah pengenbangan bisnis yang kiranya akan berpengaruh terhadap kebutuhan konsumen secara umum. iGrow dalam hal ini tampak sangat menyadari fintech bagi dunia bisnis.

\section{SIMPULAN}

Berdasarkan analisis diatas, maka implementasi fatwa Dsn Nomor 117/DSN-MUI/I//2018 tentang Layanan Pembiyaan Berbasis Teknologi Informasi Berdasarkan Prinsip Syariah terhadap PT. iGrow resources. Bahwa PT. iGrow tidak turun langsung dalam proses pinjam meminjam tetapi menyediakan platform berbasis teknologi digital dalam memfasilitasi proses pinjam-meminjam. Perkembangan teknologi dan informasi khususnya Peer to Peer (P2P) Lending telah menciptakan inovasi layanan keuangan berbasis fintech menjadi semakin praktis dan modern. Konsep adaptasi perkembangan teknologi yang dipadukan dengan bidang financial oleh iGrow merupakan langkah pengembangan bisnis yang sangat menyadari kebutuhan fintech bagi dunia bisnis. Terkait sejauh mana prinsip syariah yang diterapkan dalam PT. iGrow, dapat dilihat pada pembahasan akad dalam kontrak. Disimpulkan, kontrak baku belum sesuai dengan prinsip syariah berdasarkan fatwa DSN nomor 117/DSN-MUI/I//2018 tentang layanan pembiyaan berbasis teknologi informasi berdasarkan prinsip syariah. 


\section{Fastabiq: Jurnal Studi Islam \\ ISSN 2723-0228}

Vol. 2 No. 1 Bulan Juni Tahun 2021

\section{END NOTES}

'Moch Ali Irsyad, Analisis Start Up digital iGrow dalam Implementasi Pembangunan Ekuitas Merek
Berbasis Pelanggan (Customer Based Brand Equity), Jurnal Ekonomi Perusahaan. Vol 12 No 1,
2017 . Hal, 126.
${ }^{2}$ Achmad Ali, Menguak Teori Hukum Volume 1, (Jakarta: Kencana, Cetakan ke-5, 2013), Hal, 382.
${ }^{3}$ M Roji Iskandar, Pengaturan Klausula Baku Dalam Undang-Undang Perlindungan Konsumen dan
Hukum Perjanjian Syariah, Jurnal Amwaluna, Vol.1, No. 2, 2017, Hal, 26.
${ }^{4}$ Farihah Mahmudah, "Analisis Kontrak Baku PT. iGrow Perspektif Hukum Islam (Fatwa DSN Nomor
117/DSN-MUI/II/2018 Tembiayaan Berbasis Teknologi Informasi Berdasarkan Prinsip Syariah". (Skripsi). Hal.6.

${ }^{5}$ https://igrow.asia/about\#tab_0, di unduh 9 Mei 2020.

${ }^{6}$ Aditya Panji, "Startup Pertanian iGrow Raih Investasi dari Dua Pemodal," CNN, 25 Juni 2016, di unduh 9 Mei 2020, pukul 19.16. http://www.agronet.co.id/detail/indeks/profil/1677-M-lqbalSpirirtualitas-dan-fintechiGrow

7 Ridwan Muchlis, Analisis SWOT Financial Technology (Fintech) Pembiayaan Perbankan Syariah Di Indonesia (Studi Kasus 4 Bank Syariah Di Kota Medan), Jurnal At-Tawassuth, Vol. III, No.2, 2018, Hal. 343.

${ }^{8}$ Bambang Pratama, Mengenal Lebih Dekat Financial Technology, (Yogyakarta: Andi, 2016), Hal. 12.

${ }^{9}$ Doni Wijayanto, Legal in Startup Business, (Solo: Metagraf, 2018), Hal, 6.

${ }^{10}$ Immanuel Adhitya Wulanata Chrismantianto, Analisis SWOT Implementasi Teknologi Finansial Terhadap Kualitas Layanan Perbankan di Indonesia, Jurnal Ekonomi dan Bisnis, Vol. 20, No. 1, April 2017, Hal. 134.

${ }_{11}^{11}$ Peraturan Bank Indonesia No. 19/12/PBI/2017 tentang Penyelenggaraan Teknologi Finansial

12 Trisna Taufik Darmawansyah1, Yani Aguspriyani, implementasi fintech syariah di pt investree ditinjau berdasarkan fatwa dsn-mui no: 117/dsn-mui/ii/2018 tentang layanan pembiayaan berbasis teknologi informasi berdasarkan prinsip syariah, Jurnal Ekonomi dan Bisnis Islam, Vol 3, No. 2, Oktober 2019, Hal. 218.

${ }^{13}$ Fintech Office Bank Indonesia, Financial Technology Perkembangan dan Respons Kebijakan Bank Indonesia, (Jakarta: Bank Indonesia, 2017), Hal.13.

${ }^{14}$ Huriyah Raih Cita, dkk, Kedudukan Hukum Kreditur Baru Penerima Pengalihan Piutang Tanpa Persetujuan Agen dan Peserta Sindikasi Lainnya, Jurnal Bina Mulia Hukum, Vol. 3 No. 1, 2018, Hal. 32.

${ }^{15}$ Fatwa DSN MUI Nomor 117/DSN-MUI/II/2018 tentang Layanan Pembiayaan Berbasis Teknologi Informasi Berdasarkan Prinsip Syariah

${ }^{16}$ Ibid., Hal, 9.

${ }^{17}$ Ibid., Hal, 10 .

${ }^{18}$ Ibid., Hal, 11.

${ }^{19}$ Ibid., Hal,12.

${ }^{20}$ Ibid., Hal,12.

${ }^{21}$ Ibid., Hal.14.

22 https://igrow.asia/v1/about

${ }^{23} \mathrm{hhttp}: / /$ www.agronet.co.id/detail/indeks/profil/1677-M-lqbal-Spirirtualitas-dan fintechiGrow, di unduh 11 Mei 2020. Pukul 11.00.

${ }^{24}$ www.igrow/ product

${ }^{25}$ Dwi Murdaningsih, "Fintech Syariah Bisa Bantu Pertanian", Republika.co.id, 30 September 2017.

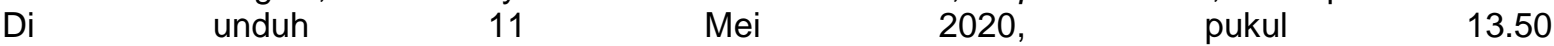
https://republika.co.id/berita/ekonomi/fintech/17/09/30/ox37g1368-fintech-syariah-bisabantupertanian

${ }^{26}$ Peraturan Bank Indonesia Nomor 19/12/PBI/2017 Tentan Penyelenggaraan Teknologi Finansial, Pasal 1 angka 1.

${ }^{27}$ https://igrow.asia/about\#tab_0, di unduh 9 Mei 2020. 


\title{
Fastabiq: Jurnal Studi Islam
}

\author{
ISSN 2723-0228
}

Vol. 2 No. 1 Bulan Juni Tahun 2021

${ }^{28}$ Fatwa DSN MUI Nomor 117/DSN-MUI/II/2018 tentang Layanan Pembiayaan Berbasis Teknologi Informasi Berdasarkan Prinsip Syariah.

${ }^{29}$ Farihah Mahmudah, "Analisis Kontrak Baku PT Igrow Perspektif Hukum Islam Fatwa DSN Nomor 117/DSN-MUI/II/2018 Tentang Layanan Pembiayaan Berbasis Teknologi Informasi Berdasarkan Prinsip Syariah". (Skripsi). Hal. 70.

${ }^{30}$ Ibid. Hal. 70

${ }^{31}$ lbid. Hal. 71.

${ }^{32}$ hhttp://www.agronet.co.id/detail/indeks/profil/1677-M-lqbal-Spirirtualitas-dan-fintechiGrow, di unduh 11 Mei 2020. Pukul 11.00.

33 Fatwa Dsn Nomor 117/DSN-MUI/II/2018 Tentang Layanan Pembiyaan Berbasis Teknologi Informasi Berdasarkan Prinsip Syariah.

${ }^{34}$ Farihah Mahmudah, "Analisis Kontrak Baku PT Igrow Perspektif Hukum Islam Fatwa DSN Nomor $\begin{array}{lc}\text { 117/DSN-MUI/II/2018 } & \text { Tentang } \\ \text { Berbasis Teknologi Informasi Berdasarkan Prinsip Syariah". (Skripsi). Hal.74 }\end{array}$

${ }^{35}$ Fatwa Dsn Nomor 117/DSN-MUI/II/2018 tentang Layanan Pembiyaan Berbasis Teknologi Informasi Berdasarkan Prinsip Syariah. 


\section{REFERENSI}

Aditya Panji, "Startup Pertanian iGrow Raih Investasi dari Dua Pemodal," CNN, 25 Juni 2016, diunduh tanggal 9 Mei 2020, Pukul 14.16

Ali, Achmad, 2013, Menguak Teori Hukum Volume 1. Jakarta: Kencana,.

Chrismantianto, Immanuel Adhitya Wulanata, 2017. Analisis SWOT Implementasi Teknologi Finansial Terhadap Kualitas Layanan Perbankan di Indonesia, Jurnal Ekonomi dan Bisnis, Vol. 20, No. 1, April.

Dwi Murdaningsih, "Fintech Syariah Bisa Bantu Pertanian", Republika.co.id, 30 September 2017.

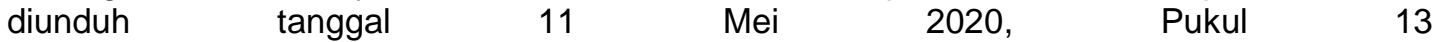
50.https://republika.co.id/berita/ekonomi/fintech/17/09/30/ox37g1368-fintech syariahbisabantu-pertanian

Fatwa DSN MUI Nomor 117/DSN-MUI/II/2018 tentang Layanan Pembiayaan Berbasis Teknologi Informasi Berdasarkan Prinsip Syariah

Fintech Office Bank Indonesia, 2017, Financial Technology Perkembangan dan Respons Kebijakan Bank Indonesia. Jakarta: Bank Indonesia.

Huriyah Raih Cita, dkk,, 2018. Kedudukan Hukum Kreditur Baru Penerima Pengalihan Piutang Tanpa Persetujuan Agen dan Peserta Sindikasi Lainnya, Jurnal Bina Mulia Hukum, Vol. 3 No. 1.

http://www.agronet.co.id/detail/indeks/profil/1677-M-lqbal-Spirirtualitas-dan-fintechiGrow, diakses 11 Mei 2020, Pukul 11.00.

https://igrow.asia

Irsyad, Moch Ali, 2017. Analisis Start Up digital iGrow dalam Implementasi Pembangunan Ekuitas Merek Berbasis Pelanggan (Customer Based Brand Equity)", Jurnal Ekonomi Perusahaan. Vol 12 No 1.

Iskandar, M. Roji, 2017. Pengaturan Klausula Baku Dalam Undang-Undang Perlindungan Konsumen dan Hukum Perjanjian Syariah, Jurnal Amwaluna, Vol.1, No. 2.

Mahmudah, Farihah, 2019, "Analisis Kontrak Baku PT iGrow Perspektif Hukum Islam (Fatwa DSN Nomor 117/DSN-MUI/II/2018 Tentang Layanan Pembiayaan Berbasis Teknologi Informasi Berdasarkan Prinsip Syariah", (Skripsi). Jakarta: Fakultas Syariah dan Hukum UIN Syarif Hidayatullah.

Muchlis, Ridwan, 2018. Analisis SWOT Financial Technology (Fintech) Pembiayaan Perbankan Syariah Di Indonesia (Studi Kasus 4 Bank Syariah Di Kota Medan), Jurnal At-Tawassuth, Vol. III, No.2.

Peraturan Bank Indonesia No. 19/12/PBI/2017 tentang Penyelenggaraan Teknologi Finansial

Pratama, Bambang, 2016, Mengenal Lebih Dekat Financial Technology. Yogyakarta: Andi.

Trisna Taufik Darmawansyah dan Yani Aguspriyani, implementasi fintech syariah di pt investree ditinjau berdasarkan fatwa dsn-mui no: 117/dsn-mui/ii/2018 tentang layanan pembiayaan berbasis teknologi informasi berdasarkan prinsip syariah, Jurnal Ekonomi dan Bisnis Islam, Vol 3, No. 2, Oktober, 2019.

Wijayanto, Doni, 2018, Legal in Startup Business. Solo: Metagraf. 